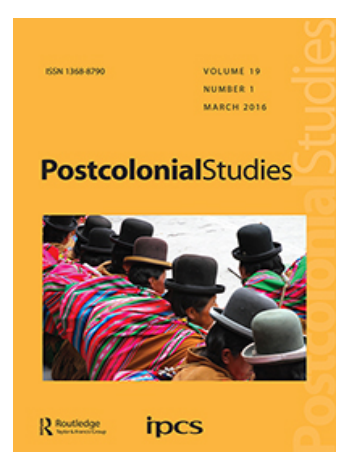

Postcolonial Studies

\title{
Worlding Sexualities under Apartheid: From Gay Liberation to a Queer Afropolitanism
}

\section{Kanika Batra}

To cite this article: Kanika Batra (2016) Worlding Sexualities under Apartheid: From Gay Liberation to a Queer Afropolitanism, Postcolonial Studies, 19:1, 37-52, DOI: $10.1080 / 13688790.2016 .1222857$

To link to this article: http://dx.doi.org/10.1080/13688790.2016.1222857

曲 Published online: 28 Aug 2016.

Submit your article to this journal $\pi$

Џll Article views: 177

Q View related articles $\asymp$

View Crossmark data $\asymp$ 


\title{
Worlding Sexualities under Apartheid: From Gay Liberation to a Queer Afropolitanism
}

\author{
KANIKA BATRA
}

In 1982 when the Gay Association of South Africa (GASA) established its offices in Hillbrow, the area was bustling with activity. A host of businesses, residential complexes, bars, and restaurants made Hillbrow the locus of an emerging gay and lesbian presence in the country. On a 2012 visit to Gay and Lesbian Memory in Action (formerly the Gay and Lesbian Archives of South Africa) in Johannesburg, archivist Gabriel Hoosain accompanied me on a Queer Walking Tour of Hillbrow, a cultural historical experience that I hope to translate in this essay. The area is no longer the gayborhood it was in the 1980s and 1990s. There are some buildings and spots which stand out as legendary: Connections, which began as a gay bar about three decades ago, but soon became a popular venue for lesbians; Skyline bar, where the first pride parade was planned; and the corner of Twist and Pretoria streets named after the black gay activist Simon Nkoli. Today, though there are identifiable gay areas in Johannesburg, the venues for socializing and activism are found in various locations in and around the city. ${ }^{1}$ There are many ways of accessing this period when inner-city Johannesburg areas such as Hillbrow, Berea, Joubert Park, and surrounding locations, emerged as a hub of gay socializing and activism. Examining gay journalism as gay liberation literature, this essay forwards a cultural history of sexuality informed by comparative urban and queer studies. My main argument is that gay liberation literature under apartheid lags behind important shifts in sexual activism; and my larger aim is to extend the valences of postcolonial queer studies towards a historical examination of North-South interactions in theorizing sexual activism. ${ }^{2}$ Gay liberation literature here refers to texts which contributed to the emergence of a gay and lesbian sexualities in South Africa, including works of fiction, poetry, drama, anthologies as well as newsletters, newspapers, and newsletters. ${ }^{3}$ The primary archive used as an example of gay liberation literature is Link/Skakel, the official newsletter of the GASA, which later became a mainstream gay newspaper called Exit.

The analysis offered here extends into the domain of sexuality what Aihwa Ong has recently theorized as 'worlding projects' of emergent global formations which 'seem to form a critical mass in urban centers, making cities both critical sites in which to inquire into worlding projects, as well as the ongoing result and target of specific worldings'. Achille Mbembe's elaboration of Taiye Selasie's term 'Afropolitanism' to the realm of urban studies is important to my analysis of the worlding of sexualities under apartheid. Mbembe posits Johannesburg as the 
centre of Afropolitanism, based on its 'multiple racial legacies, a vibrant economy, a liberal democracy, a culture of consumerism that partakes directly of the flows of globalization'. ${ }^{5}$ Mbembe's and Sarah Nuttall's discussion of Johannesburg as an Afropolis extends the theoretical valence of Afropolitanism to a cityscape marked by change and reinvention.

An overly celebratory view of Afropolitanism has been countered by discussions of easy access to mobility across borders, consumerist and elitist connotations of the term, and its exclusions. Simon Gikandi's foreword to a 2011 collection titled Negotiating Afropolitanism strikes a cautionary note by mentioning how the term which can be 'read as the description of a new phenomenology of Africanness - of being African in the world' also invites a consideration of 'the negative consequences of transnationalism, the displacement of Africans abroad, the difficulties they face as they try to overcome their alterity in alien landscapes, the deep cultural anxieties that often make diasporas sites of cultural fundamentalism and ethnic chauvinism'. ${ }^{6}$ Among others, Binyavanga Wainaina and Yewande Omotoso have taken issue with Afropolitanism as a descriptor of a literary or social condition. Indeed Wainaina's memoir One Day I Will Write About This Place (2011) can be read a gloss on Afropolitanism. Here multiple linguistic influences, an anglicized education, the experience of intra-African migration, awareness of sexual difference, and international literary acclaim prefigure the emergence of a sexual identity. Wainaina critiques the term Afropolitan in favour of "panAfrican' in his 2012 address to the UK African Studies Association. Similarly, the South African novelist Yewande Omotoso comments on the term as 'useful for the West as it gives the West an opportunity to understand and even "consume" Africa'. 7 There are different ways of being Afropolitan: migratory, consumerist, and Western-oriented; localized, anti-consumerist, and Africa-oriented.

Acknowledging various aspects and uses of Afropolitanism and its important critiques, my focus is on specific forms of worlding to analyse the transformation of a predominantly white male gay activism in Johannesburg from the 1980s to the1990s. Mbembe and Nuttall describe Johannesburg as 'a thoroughly polyglot urban formation whose influence, connections, and identifications extend beyond its locality and well beyond South Africa' ${ }^{8}$ Afropolitanism, which this essay both invokes and places under erasure, when prefixed with queer, helps me think of connections between the movement for sexual rights and the antiapartheid movement arising within a specific urban metropolitan context, but extending beyond it to national and transnational spaces and contexts. My purpose is to further discussion around the term through the juxtaposition in 'queer Afropolitanism', and to present its generative potential for debates on literary, national, and sexual identity. ${ }^{9}$

A key concept connecting the anti-apartheid and sexual activism is 'visibility'. Ashley Currier writes that social movements desire both visibility and invisibility at different times, and this was certainly true of the gay liberation movement in Johannesburg. GASA's 'cultivated apolitical visibility' dictated in part by concerns of safety in the early 1980s, was followed by pressure by black and lesbian GASA members to abandon the apolitical stance in favour of alliance with the anti-apartheid movement in the mid-1980s and 1990s. ${ }^{10}$ In the early 1980s gay activists demanded legal change and political representation but did not pursue a broad 
conception of rights inclusive of racial and sexual equality. In a retrospective look at GASA and in response to the question 'Where were you in the eighties?' Ann Smith, one of the founding members of the organization, mentions that rather than see 'oppression as a continuum', the creation of a 'safe space in which gay men and women could meet and interact without fear of being condemned, brutalized, shamed, humiliated or arrested' constituted a 'gay liberation movement' for the organization. ${ }^{11}$ Early 1980 s gay efforts were often directed towards claiming urban and national spaces without challenging segregation, reflecting a distinctly narrow conception of rights based on consumerist sexual identities. Indeed, the earliest essay on Exit and gay publishing in South Africa by Gerry Davidson and Ron Nerio, describes how despite the state of Emergency in 1986 and 1987, the newspaper 'focused almost totally on parochial affairs' and continued to 'reflect the white gay establishment's attitudes by steering clear of politics'. ${ }^{12}$ A genuine desire for inclusivity was expressed by a few of the GASA members, among them lesbians in the organization. Often these efforts were hampered by GASA's apolitical cautionary reformist orientation. It was only in the late 1980s that the gay and lesbian collectivity engendered in Hillbrow and sustained through print came to be identified as 'queer'. Brenna Munro and Chantal Zabus take up the valences of queer in African contexts by strategically using the label and challenging its Euro-American connotations. ${ }^{13}$ While it is accurate to note the use of queer in the African context as a 'shorthand for practices that cannot be fully subsumed into identitarian labels of lesbian, gay, transgender, bisexual, or those that cannot be adequately translated into European languages', my call is for a specificity in the deployment of the term based on historical, national, and activist contexts. ${ }^{14}$ To this end, my suggestion is that in the South African context queer marks the emergence of an intersectional politics that connected the anti-apartheid and gay and lesbian rights movements.

Recognition of and respect for racial, cultural, geographical, and gender differences within the gay movement, building connections between multiple forms of oppression, and a conscious effort at international connections best describes the worlding of sexualities in the changing political climate of apartheid South Africa. ${ }^{15}$ As revealed in the pages of Exit, the emergence of a sexual subculture in Johannesburg was initially influenced by models of gay consumerism and activism in the North with a disregard for inequities created by racial, gender, and class privilege. However, the direction of comparison from North-South and the exclusivist racial and gendered assumptions were challenged first by lesbians in GASA and later, black activists from the Gays and Lesbians of Witwatersrand (GLOW). These groups urged for attention to racialized, gendered, and non-metropolitan articulations of sexuality, a process which has continued in the ongoing interrogation of South Africa's historic enshrinement of gay and lesbian rights co-existing with increasing levels of homophobia in cities and townships, still tarmarked with sexualized violence.

\section{Profit and Pleasure in the Afropolis}

Many studies of Johannesburg focus on the dissolution of spatial segregation from the 1980s onwards, which led to some areas becoming more racially diverse than 
had been the case in the previous decades. ${ }^{16}$ In this respect, Johannesburg can be compared with other African cities which have been analysed as sites of discursive, economic, cultural, and social transactions and as gendered, raced, and sexualized spaces. ${ }^{17}$ Loren Kruger's description of Johannesburg as an 'edgy city' describes the 'pervasive nervousness expressed by blacks and whites in the face of crime and grime in the 1990s ${ }^{18}{ }^{18}$ The story of the passage of time in Johannesburg and its difficult transition from racial exclusivity to a mixed-race, grey space in the 1980s and 1990s establishes a direct connection between desegregation and the 'flight' of white people from the inner city to the suburbs. ${ }^{19}$

This section describes patterns of gay life and consumption in Johannesburg represented by Link/Skakel as directly linked to the processes Ong labels 'urban modelling' and 'inter-referencing' where the initial trajectory of influence from the North to the South acquires an African worldliness following the dissolution of spatial segregation. ${ }^{20}$ One of the earliest studies to discuss the slow process of desegregation in the context of economic growth, urban architectural needs, and housing scarcity for black and coloured people, Nigel Mandy's work is also important for describing how the North American city model was adopted by Johannesburg planners. ${ }^{21}$ This model arguably influenced white gay subculture from the 1960s onward, though Mandy does not directly address this. Noting this connection, Neville Hoad observes the 'superficial sameness to commercial gay life (representationally white) in the major South African metropolises that is recognizably North American urban'. ${ }^{22}$ The historical evolution of this sexual subculture therefore needs to be examined in ways that are local, national, and transnational. In a commonly repeated explanation Mandy mentions that the Group Areas Act of 1950 ensured that 'voluntary' ethnic residential separation, a natural feature of all cities, became a formalized and involuntary process. ${ }^{23}$ Mandy recounts in great detail the long struggle for desegregation of inner-city restaurants from the 1970s onwards by using those in the Carlton Center as an example. Kruger's description of the Carlton Center as a 'site of apartheid absurdity' where the restaurant was open to 'international' blacks including Bantustan bureaucrats, but not to black township residents' further glosses the spatial inequalities of the era. ${ }^{24}$ The free market rationale used to justify such desegregation echoes the propaganda of the Association of Chambers of Commerce of South Africa (Assocom) that the growing city economy demanded a desegregated city space where blacks were free to secure gainful employment and to avail services offered in the city as consumers. ${ }^{25}$

These two contexts - that of the city as modelled on North American urban development; and the growing presence of black, coloured, and Indians as workers and consumers following the relaxation of petty apartheid principlescharacterize Hillbrow's emergence as a gay area in the 1980s and its apparent 'degeneration' in the 1990s. Increased international attention on South African racial policies in print and other media, combined with an acute housing shortage for black and coloured people in Johannesburg, led to the slow integration of the city, explaining the change in Hillbrow from an upscale white to a reluctantly integrated neighbourhood. Building on Alan Mabin's important work, Beall, Crankshaw, and Parnell observe that during 'the 1970s and 1980s, inner-city residential areas continued to enjoy a bohemian reputation, a flourishing urbanism 
unknown anywhere else in South Africa, ${ }^{26}$ In a sense then, the flourishing Afropolitanism of the 1980s and 1990s was as much due to established non-African models of commercial and residential planning as it was due to the sexual, racial, cultural, economic, and national diversity of the inhabitants.

This then was the urban context for the emergence of Link/Skakel (hereafter $L / S$ ), the official newsletter of the GASA, published simultaneously in English and Afrikaans, creating an 'imagined community' in Johannesburg through the medium of print. The inaugural $L / S$ published in May 1982 mentions that at its first meeting, GASA, an amalgam of three organizations, Lambda, Unite', and Amo, discussed 'subjects as diverse as the need for community service, welfare, law reform, the improvement of the gay image, the establishment of a gay identity, entertainment, and subjects of a more organisational nature'. ${ }^{27}$ Thus the publication's activistinformational-consumerist purpose is evident from the beginning. Mark Gevisser's comprehensive review of the South African gay and lesbian movement from the 1960s to the 1990s in Defiant Desire mentions there was never a clear demarcation between the social and organizational needs of GASA. ${ }^{28}$ This is reflected in the contents of the first newsletter which contains an announcement to compile a Pink Pages Telephone Directory where 'business concerns can advertise under appropriate headings' as well as information about membership dues to the organization. ${ }^{29}$ The first few newsletters are a dazzling display of conspicuous consumption, with advertisements from gay-friendly businesses offering luxury commodities including cosmetics, flowers, jewellery, clothes and furnishings, and international travel services. In addition, there are a number of 'news' reports on various gay-friendly restaurants. The circulation of capital and services to world these emerging sexualities are a key feature of gay and (to a lesser extent) lesbian lives in the Afropolis in the 1980s. As Graeme Reid's work on gay identities in 'small-town' South Africa demonstrates, the consumption of 'fashion, style, and glamour' remain a key feature of gay lives in the post-apartheid scenario even away from the centre of the Afropolis, a queer Afropolitanism that is refigured in peri-urban locations. ${ }^{30}$

The relation between capitalism, migration to urban areas, and gay identity is applicable to Hillbrow which was already recognized as a bohemian inner-city area before it became the centre of gay socialization and activism in the $1980 \mathrm{~s}^{31}$ The visibility and activism of lesbians in Johannesburg can be documented in relation to (and not distinct and separate from) dominant gay male activism in GASA and later in queer politics in South Africa in the 1980s and 1990s, as evidenced by Karen Lotter and Ann Smith's participation in GASA and regular contributions to its official newsletter. Lotter and GASA Rand's chairperson, Smith's articles on social lesbianism, lesbian identity, role playing, and radical lesbian opposition to gay liberation ensured that lesbians had a voice in GASA and its print publications. ${ }^{32}$ Lesbian women also obtained access to spaces such as restaurants and bars, indicating a trajectory of socialization and activism that spatially converges with but ideologically diverges from that of white and Afrikaaner gay men. For example, a venue such as Buddies on Twist Street, which first advertised itself as an 'all male bar/disco', continued to remain gender segregated for a while before revisiting its strategy and marketing itself anew as a 'private club' open to 'men and women'. ${ }^{33}$ Other establishments realized that there was money to be 
obtained from a lesbian clientele, and abandoned the policy of bars and clubs as exclusively male spaces.

While participating in the worldliness of metropolitan gay life offered by Johannesburg, black gay men and lesbians often found themselves sidelined both from the movement as well as from its patterns of consumption. The next section examines some of the legal challenges to governmental jurisdictions on sexuality and race that inhibited an egalitarian worlding of sexualities.

\section{Law, Politics, and 'Community'}

Of the laws on record, the Immorality Act of 1957, later renamed the Sexual Offences Act, banned sexual relations between all whites and non-whites. Until the ban was lifted in 1985, homo or heterosexual relations between people of different races were proscribed under this act. The history of law reform by gay and lesbian activists can be charted to the 1960s when the apartheid government introduced amendments to existing legislation that sought to include homosexuality under its purview. The gay community came together to form the Law Reform Movement in 1968 in an effort to prevent draconian applications of the Immorality Act against homosexuals. Gevisser observes that the movement was 'successful' inasmuch as only three amendments to the current law were proposed: raising the age of consent from 16 to 19, outlawing dildos, and the prohibition of sexual activity between men at a 'party', where party was defined as the presence of more than two people. Besides these restrictions applicable to all, black people were not permitted to move into the city through the provisos of the Group Areas Act of 1950 which was amended several times in the 1960s and 1970s to exclude them from living in developed urban areas. The act was untenable in Johannesburg from the 1970s onwards when a shortage of housing and development of the service economy led to increasing, though technically illegal, migration to the city.

Identity based movements in the Global South, especially women's and LGBT movements, are often analysed in terms of victimhood due to their focus on social and legislative discrimination as the basis of sexual rights activism. ${ }^{34}$ Despite many discriminatory laws on record during apartheid, gay men and lesbian women combatted the description and ascription of victimhood by focusing on law reform in the 1960s, community education during the 1980s, and political involvement in the 1990s, as documented in L/S/Exit. Mbembe identifies a refusal of victim status as one of the key attributes of Afropolitanism, yet gay activists' struggle against victimhood was sometimes marked by a suspect racial and gender politics that prefigured the demise of GASA and a move away from the original aim of its publications. ${ }^{35}$ In this GASA's stand was no different from that of a similar organizations in North America, for instance, the Gay Activists Alliance, which followed a 'single issue politics' in the 1980s that, according to Urvashi Vaid, operated 'under the assumption that gay rights are related to but disconnected from other kinds of civil freedom, ${ }^{36}$ Reformist rather than radical in its orientation, GASA followed a controversial trajectory of selective legal reform as evident in its newsletter.

During the first two years of its publication, $L / S$ took its role of educating the gay men in the city about their rights very seriously. A column by Michael titled 'You 
and the Law', published regularly from 1982 onwards, addressed several common problems faced by gay men including their status within Common Law, information on statutory offences, on being accosted by the police, and on procedures of criminal cases. ${ }^{37}$ Since lesbian sexuality was not under the purview of the Immorality Act Amendment, and black movement in the inner city came under the Group Areas Act, the primary and implied readership of these articles were urban, gay men who risked persecution by cruising in public spaces. Identified only as the GASA lawyer, Michael attempted to address the rights of couples from different races in June 1983 in response to several queries about the 'question of occupation of residential premises', particularly if the 'association is between people of different colour'. His final advice to people of different races cohabiting in an urban area is 'You need a sympathetic area, a sympathetic landlord, and nerves of steel to be able to feel at all comfortable about it. ${ }^{38}$ Other legal advice offered in the newsletter was about violation of privacy, intimidation, employment rights of sexual minorities, wills and the rights of partners in gay relationships, and rights of gay parents after divorce from a heterosexual partner. In summary, this column offered comprehensive legal advice in non-specialist, accessible language for a largely white, gay male readership.

Gay liberation literature faced other challenges including censorship. In early 1984 the April and May numbers of $L / S$ were sent to the Directorate of Publications in Capetown as samples after its registration as a newspaper for public sale. However, since the Publications Act applied only to commercial publications, in August 1984 it was decided to cancel the registration of $L / S$ as a newspaper and to distribute it free of cost to members of GASA. The movement's awareness of gay people's right to the city which was apparent in the advertisements and columns of the newsletter, and the threat of persecution under the Publications Act, led to strategic changes both in the nature of activism and its official publication. From July 1985 onwards $L / S$ was converted to Exit, described as 'totally independent and not connected to any gay organisation or group' ${ }^{39} \mathrm{~A}$ specific instance of this independence is the discontinuation of 'You and the Law', perhaps because of GASA's increasing focus on a broader campaign for law reform.

Taking inspiration from the Law Reform Movement in the 1960s when the gay community had come together to fund a legal campaign, a similar move was attempted in the 1980s. Law reform became a nationwide effort in 1986, partially in response to incidents such as the Vice Squad raid on the GASA convention in Johannesburg that year. The setting up of the Legal Reform Fund in early 1986 and a fundraising effort called Benefit to collect R 100,000 for legal costs was announced with much fanfare in the pages of Exit in October 1985. ${ }^{40}$ Gevisser, a distinguished journalist, gay rights advocate, and supporter of the campaign, has written about the discrepancy between the grandiose aims and disappointing consequences of the campaign using 1968 as a point of comparison:

Unlike 1968, however, there was not the same government focus: PW Botha's campaign to smash anti-apartheid resistance overtook all else and the gay issue was forgotten. The NLRF [National Legal Reform Fund] had raised R 59,000 by January 1987, but had nothing to spend it on: it was thus transformed into the National Law Reform Charitable 
Trust. Three trustees were appointed, and it was decided that this money would be used in future to 'market gay lifestyles' and to intervene, in any possible way, in the gay law reform struggle in South Africa. Of the 59,000 raised, however, only R10, 000 was spent, and there was much dissatisfaction within the gay community: talk abounded of misappropriation of funds. ${ }^{41}$

Not only was the national fund used for purposes other than those for which it was originally intended, but its largesse was restricted to metropolitan urban locations where gay lifestyles were already being marketed through venues such as Exit. The damning charges of corruption and misuse of funds by key GASA members in 1986 were followed by debate over the organization's support of the National Party candidate Leon de Beer from Hillbrow in the 1987 elections. ${ }^{42}$ By proclaiming in the headlines that 'Election was Gay Victory' the publishers of Exit were clearly defining white gay interests in electoral and spatial terms. This announcement of the gay 'community's' role in swinging politics was followed by a declaration that the "community will get a far better deal from the Johannesburg City Council in the future' and that this is 'directly attributable to the election result in Hillbrow and the coming by-election determining who will rule Johannesburg'. ${ }^{43}$ Gay voters questioned the candidates belonging to various parties, expressed their concerns about obtaining space for the Gay Advice Bureau and accessing other city amenities. However, as before, a myopic advocacy of gay rights to city spaces did not include an acknowledgment of restrictions on black and coloured populations. ${ }^{44}$ Such blindness was publicly challenged by the Wits Gay Movement (WGM), which made it clear that the newspaper and its current editor, David Moolman's support of de Beer and his 'arrogance' in claiming to speak for the entire gay community equated gay rights with white gay rights. A WGM letter in Exit points out that when 25 million people in South Africa are denied the right to vote, the correct stand should be 'against racism, sexism, and all forms of discrimination'. ${ }^{45}$

Besides limited voting rights, the National Party's stand on maintaining apartheid brought the Group Areas Act into the limelight at a time when gay voters were deciding on which candidates would best represent their interests. Despite the awareness that the Group Areas Act privileged white people's use of city space, Exit made no attempt to address the issue in its list of questions to the party nominees. Calling out this tunnel vision as a sign that the community was distinctly limited in its outlook, one reader asked: "Are we voting for a "Gay Group Area?" If so, please count me out. ${ }^{46}$ The Cape Town based Lesbians and Gays against Oppression or the LAGO collective publicly repudiated Leon de Beer's election as Nationalist MP in Exit. LAGO pointed out the contradictions in the National Party's ideology and in the political awareness of gay voters in Hillbrow:

How can anyone committed to democracy support a candidate whose party has been responsible inter alia, for the forced removals of thousands of families to enclaves of rural deprivation, the arbitrary incarceration of hundreds of children and the systematic abuse of police powers with the concomitant abrogation of the rule of law'. ${ }^{47}$

While the Group Areas Act was finally repealed in 1990, GASA and the urban gay community's avoidance of the race question exposed the faultlines in the 
movement. These incidents reveal the failing fortunes and ineffectiveness of GASA in the late 1980s, an ineffectiveness which was brought to national and international attention in the movement's and its associated publications' handling of the Treason Trials involving Simon Nkoli.

\section{Queer Afropolitanism}

With the official repeal of the Immorality Act in 1985, a new generation of activists committed to worlding sexualities through an intersectional anti-apartheid queer politics sought to use popular publication avenues such as Exit. One of the leading figures in this move was Simon Nkoli who had been an active member of GASA from the early 1980s. Establishing $L / S$ and Exit's presentation of race is crucial to understand the political divergences within the organization. Even at its inception, $L / S$ could not afford to be seen as overtly racially biased. The early $L / S$ numbers contain articles which purport to understand black gay identities and cultures. The newsletter also carried a few racially inclusive advertisements from gay-friendly businesses such as Ebony casual and designer clothing housed in Melville and Browser's picture framing in Hillbrow. ${ }^{48}$ Minimally inclusive ones included those by Stud Barn restaurant (racially coded towards a coloured clientele) and by Jameson's bar on Commissioner Street which had applied for an 'international' license allowing it to serve black customers. Most advertisements were unambiguous in their preference for white customers, and many did not welcome women. The suggestive and unabashedly pretentious names-Connections, Chittendales, Saddle, Parzival, Heaven, Butterfly, Cranks, etc.- - targeted white gay men with sufficient disposable incomes as consumers.

Not only the services advertised in its newsletter but also the social activities organized by GASA were often racially exclusive. For instance, an outing organized by the GASA Rand hiking group towards the end of 1983 was critiqued for being a white only excursion. In response to this criticism, the editor defends the exclusivity by stating, 'The fact that there are no multiracial venues in Pretoria is something that cannot be blamed on Gasa. Even in the Johannesburg area the number of venues open to all races can be counted on one hand. ${ }^{49}$ These incidents exposed GASA's hypocritical claims of being welcoming of all races and rendered suspect $L / S$ 's goals of serving as a means of gay liberation. Such a stand led to GASA's internal disagreements with its lesbian and more progressive members and an embattled relationship with the International Gay Association (later renamed the International Lesbian and Gay Association or ILGA). In a chronological review of this relationship from the later 1980s to the end of the decade, Jens Rydström observes that when GASA had applied for membership to the IGA in 1983, the application had been opposed by the Scottish Human Rights Groups (SHRG) on the grounds that the organization's politics was not inclusive. ${ }^{50}$ GASA's representative Pieter Bosman managed to convince IGA to ignore SHRG recommendations. Ironically, since the majority of IGA members voted in favour of GASA, this was reported as a victory in Exit in the August 1987 headline 'International Body Welcomes SA Gays'. ${ }^{51}$ Rather than take international opposition to GASA as a moment for self-reflection and scrutiny, the organization and the newspaper applauded Bosman and Smith's lobbying efforts. In 1986, at the 
insistence of SHRG and some other anti-apartheid groups in ILGA, GASA's racial politics again came under scrutiny. This time the opposition came from Swedish and Scottish groups, and GASA sent Kevan Botha as a representative to prevent its expulsion from the organization. Botha's apparently candid account of GASA's multiracial work helped avoid the organization's expulsion, an account he later admitted had been insincere in its representation of GASA's political stand on race and apartheid era exclusions.

Behind the scenes others had been working to avoid this expulsion. While in detention as a co-conspirator in the Delmas Treason Trial, Nkoli had written to the ILGA pleading with them not to expel GASA from its fold. In later years this connection helped the international community become aware of the mutual imbrications of racial and sexual justice, particularly when African LGBT organizers, including Nkoli and Sheila Lapinsky, attended the annual ILGA conferences. Phumi Mtetwa, a black lesbian activist, who served with Nkoli on the National Coalition for Gay and Lesbian Equality, was elected as Secretary of ILGA from 1999 to 2001. Hence the impact of a black South African perspective on ILGA which had a predominantly European and North American focus till the mid1980s cannot be overstated.

Nkoli's involvement with GASA and Exit lasted through his detention from 1985 to 1988 in one of the longest running and most widely publicized political trials in South Africa documented in gay as well as mainstream South African history. ${ }^{52}$ It brought to international attention GASA's limited view of justice and rights. When the organization did comment on the incident, many months after Nkoli's arrest, it was in a short piece appearing in Exit which justified not taking an 'official stance' since Simon 'is not detained because of his gay activities'. ${ }^{33}$ Ann Smith, Chairperson of GASA Rand and International Secretary of GASA for many years, pointed out the contradictions in the organization's stand and made clear her own position and differences. ${ }^{54}$ Many lesbians in the movement did not share the official GASA position that was reflected in the newspaper, despite the claims of the publication being an independent entity. In the late 1980s Exit was edited jointly by Karen Lotter and Henk Botha before their disagreements over GASA's racial politics led to the latter giving up his second stint at editorship.

In this context, Nkoli's founding of the Saturday Group within GASA in 1984 signals an emerging queer Afropolitanism that expands the racial and geographical reach of gay liberation, a worlding of sexualities that was first, simultaneously local, national, and international and next, openly political and communityoriented. From 1984 GASA had taken some note of worlds other than the one in Hillbrow by supplementing the local gay news column 'Link up' with one called 'World Link' containing snippets of gay and lesbian news from international sources, indicating an awareness of its role in the global circulation of gay liberation literature. In this worldly context where white gay activism was increasingly becoming untenable, a small inconspicuous notice placed by 'Simon and Roy' in $L / S$ announced: 'Gays of all races, sexes, ages and creeds are welcome. ${ }^{55}$ The Saturday Group soon acquired its own offices and planned a series of activities which involved not just people living in Johannesburg but also township and homeland areas. The group's practices of socialization were markedly different 
from that of the white gay community, sometimes leading to hostility between the more established GASA members and those belonging to the Saturday Club. After Nkoli's acquittal in the Treason Trials, the Saturday Group resumed its activities. There is little coverage of this in Exit except through very brief letters sent by readers.

Nkoli formed the Johannesburg and Soweto Working Group, which was the precursor of the GLOW on his release and acquittal. The new organization was founded on principles of fulfilling the educational, cultural, and social needs of the black lesbian and gay community. One of the crucial aspects of queer politics in this period is a realization that city spaces cannot exclusively encompass gay and lesbian activism and that worlding sexualities involves work beyond the Afropolis. The reclamation of a black queer identity from a predominantly white GASA meant reaching out to people of all races living in the city and outside it, in townships such as Soweto and Kwa-Thema. To this end the 1988 celebration of Gay Pride by GLOW included a meeting for support for Ivan Toms, a gay activist, at the University of Witwatersrand, a drag show, and a braai, dance, and poetry reading at a private house. ${ }^{56}$

The definitional correlates of queer embraced by GLOW derived as much from African social realities as they did from the emerging models of activism by North American groups such as AIDS Coalition to Unleash Power (ACT UP) in the late 1980s and Queer Nation in the 1990s. Karen Lotter mentions Nkoli's 1989 trip to London, from where he went to Vienna to attend the ILGA meeting, and then to Canada and US to raise money for the Township AIDS Project. ${ }^{57}$ This history of exchange and influence is part of GLOW's international connections maintained by visits abroad and exchange of information about the global LGBT movement that was taking on a different face in the wake of the AIDS crisis. GLOW's efforts to address the crisis reflected awareness of queer activism in North America but also a recognition that the situation in South Africa demanded a different response. In these ways it differed from GASA's response to the crisis. Mandisa Mbali notes in her account of South African AIDS activism that GASA circulated information about AIDS through its publications and at its meetings but did not address the issue politically, and that there was some disagreement amongst its members and the publications as to the urgency of the crisis. Additionally, GASA opted to collaborate with the apartheid regime's ministry of health as a representative gay organization at a time when other organizations refused collaborations with the state. ${ }^{58}$

In contrast to GASA's model of gay liberation, Nkoli and GLOW's queer Afropolitanism involved an effort to connect races, genders, classes, within and beyond the nation when the apartheid regime was beginning to unravel. Because of its work with non-urban, underprivileged gay, lesbian, and transgender people living under threat of isolation, violence, and disease, this politics also came to be called the gay Left in South Africa. GLOW members' non-metropolitan background was one of the reasons for this focus. The varied worldly geography of GLOW's activities (by 1991 it had branches in Kwa-Thema, Tembisa, Soweto, and Johannesburg) is reflected in Nkoli's 'Open Letter to Nelson Mandela' for the Village Voice, reprinted by Exit. He attempts to make the leader understand 'what it means to be a gay or lesbian person in the townships' and establishes a 
direct link to the situation under apartheid where people, feeling unsafe in their home communities, "are moving into the so-called "grey areas" of the white cities, which also happen to be gay areas'. In a savvy move that connects the local to the global or South Africa to the world, Nkoli reminds Mandela of his promises to secure 'the rights of all people' on a visit to the Township AIDS Project in Soweto, of his support for gay rights in a meeting in Stockholm, and of the promises made by Mandela's close colleagues, Thabo Mbeki and Frene Ginwala, who had publicly declared outside of South Africa that gay rights would be secured by the African National Congress (ANC). ${ }^{59}$

Finally, the emergence of local, national, and international queer Afropolitanism of the kind articulated by lesbian women in GASA, Nkoli, Beverley Ditsie, and GLOW in Johannesburg and surrounding areas also arose due to a vacuum in gay and lesbian organizing in the wake of GASA-era politics. As reported in Exit, Alfred Machela, a black activist, had started the Rand Gay Organization (RGO) when Nkoli was in prison. But the RGO was ineffective, practically invisible, and deemed suspect by the late 1980s. Thus GLOW emerged as the natural leader for organizing the first ever Gay Pride Parade in October $1990 .{ }^{60}$ The route charted for the parade from Braamfontein to Hillbrow symbolized the educational, commercial, and social needs of the gay and lesbian community in Johannesburg, and asserted that people of all races and beliefs had a claim to this vibrant Afropolis.

The assumption that visibility characterizing annual Pride in Johannesburg in the 1990s made the city and its surroundings safer for gays and lesbians is belied by news coverage in mainstream and gay media of this period. Exit reported many incidents of homophobic violence when a national collation of gay and lesbian groups was being planned to place sexual equality in the draft South African constitution. Reid and Dersuweit mention that the visibility of gay men and lesbian women may have contributed to the rise in gay bashing. This is borne out by Beverley Ditsie's memory of the first Pride Parade which made her a public figure and hence subject to homophobic threats in her Soweto neighbourhood. ${ }^{61}$ In 1996 South Africa became the first nation in the world to constitutionally guarantee non-discrimination to its gay and lesbian citizens through what came to be called the Equality Clause, the result of a complex process of negotiations between gay and lesbian activists and the ANC, with support from the legal community. Studies conducted on the incidence of homophobic violence in Johannesburg and its environs in the post-apartheid era after this constitutional mandate conclude that the city remains a 'homophobic landscape' and that further 'investigations need to be embedded in discussions of the complexity and suppleness of gay urban politics in Johannesburg'. ${ }^{62}$ Xavier Livermon's account of black queer bodies' estrangement from freedoms enabled by the constitution, though it does not explicitly deal with urban geography, mentions that this estrangement 'cannot be resolved at the state level but must occur in communities that ultimately can provide safety and security to black queers and thus make the rights of the constitution meaningful'. ${ }^{63}$ Resonating with Brenna Munro's call of a 'queer South African sexual politics' that offers an 'alternative to the current global and national status quo, speaking back to a postaparthied social order that might prefer gays and lesbians to remain mutely happy emblems of the new nation, ${ }^{64}$ my submission is 
that the exceptionality of constitutional and legislative successes and the unexceptionality of sexual violence in South Africa are future projects for a postcolonial queer historical enquiry.

In conclusion, sidestepping GASA-era politics, gay liberation moved toward a queer Afropolitanism in the late 1980s and early 1990s. However, rather than transitioning from gay liberation to queer liberation literature, Exit lapsed into an infomercial tabloid still in circulation. Despite this disappointing trajectory, the Johannesburg based gay journalism of the 1980s emphasizes connections that complicate a one way North-South comparison. Many of these comparisons present LGBTQ mobilizing in the North as emulated in the South with few or no legislative gains. ${ }^{65}$ Within South African gay social formations there was and remains modelling and inter-referencing of Northern gay urbanisms and modes of protest, but there is also localized Southern consciousness addressing exclusions through legal reform, and modes of racial, class, and gender inclusivity, that extended sexual rights awareness beyond the gay world of Johannesburg. GASA lesbians and GLOW's invocation of and departure from Northern and international queer activism stands out as exceptional not only in the gains secured at the turn of the twentieth century but also in its ability to inflect international sexual rights activism with racial and geographical specificities. Engendered in Hillbrow, but spreading beyond it to embrace the racially, geographically, culturally diverse worlding of spatiality and sexuality in print, this queer Afropolitanism emerged in the face of obstacles encountered, overcome,${ }^{66}$ and still faced by those tirelessly working to secure justice and rights for sexual minorities in the global South. ${ }^{67}$

\section{Notes on contributor}

Kanika Batra is Associate Professor and Director of Graduate Studies at the Department of English, Texas Tech University where she teaches and researches Postcolonial Feminism, Postcolonial Queer Studies, Globalization, and Urban Studies. She is the author of Feminist Visions and Queer Futures in Postcolonial Drama (Routledge: New York, 2011).

\section{Notes}

1 Some organizations supporting sexual rights activism are located a little off inner-city Johannesburg in Braamfontein and Yeoville. These include GALA, Forum for the Empowerment of Women (FEW) in Braamfontein, the Gay Boxing Group, and the Gay and Lesbian Legal Advice Centre in Yeoville. Additionally there are several health-based organizations with centres or branches in Soweto such as SOHACA (Soweto HIV/ AIDS Health Counsellors Association) and Health4Men with clinics in and around Johannesburg. The exhibition, Joburg Tracks: Sexuality in the City, developed by GALA in 2008, is now permanently housed at Museum Africa in Newtown, Johannesburg.

2 There is a wealth of scholarship on North-South interactions in studies of sexuality. Many of these works are categorized as queer diasporic analyses. See Cindy Patton and Beningo Sanchez-Eppler, Queer Diasporas, Durham: Duke University Press, 2000; Arnaldo Cruz-Malawe and Martin F Manalansan, Queer Globalizations: Citizenship and the Afterlife of Colonialism, New York: New York University Press, 2002; Martin Manalansan, Global Divas: Filipino Gay Men in the Diaspora, Durham: Duke University Press, 2003; Gayatri Gopinath, Impossible Desires: Queer Diasporas and South Asian Public Cultures, Durham: Duke University Press, 2005. For localized as well as diasporic queer perspectives see John Hawley, Postcolonial Queer, Ser. Explorations in Postcolonial Studies, Albany: SUNY Press, 2001.

3 See the landmark anthology of lesbian and gay writing Matthew Krouse (ed.), Invisible Ghetto: Lesbian and Gay Writing from South Africa, London: Gay Men's Press, 1993. 
4 Aihwa Ong, 'Introduction: Worlding Cities or, the Art of Being Global', in Ananya Roy and Aihwa Ong (eds), Worlding Cities: Asian Experiments and the Art of Being Global, Sussex: Wiley-Blackwell, 2011, p 12.

5 Achille Mbembe, 'Afropolitanism', in Simon Njami (ed.), Hayward Gallery, Laurent Chauret (trans), Africa Remix: Contemporary Art of a Continent, Ostfildern: Hatje Cantz, 2004, pp 26-29.

6 Simon Gikandi, 'Foreword, on Afropolitanism', in Jennifer Wawrzinek and J K S Makokha (eds), Negotiating Afropolitanism: Essays on Borders and Spaces in Contemporary African Literature and Folklore, Amsterdam: Rodopi, 2011, pp 9, 11.

7 Yewande Omotoso and Rebecca Fasselt, "I'm Not Afropolitan-I'm of the Continent”: A Conversation with Yewande Omotoso', The Journal of Commonwealth Literature, 50(2), 2015, p 235.

8 Achille Mbembe and Sarah Nuttall, 'Introduction: Afropolis', in Sarah Nuttall and Achille Mbenme (eds), Johannesburg: The Elusive Metropolis. Durham and London: Duke University Press, 2008, p 25.

9 My argument acknowledges Neville Hoad's reading of Phaswane Mpe's Welcome to Our Hillbrow. Hoad points out the contradiction in the formulation 'African cosmopolitanism' where the word African 'designates a geographic, if not racial, specificity' in contrast to cosmpolitanism, which 'aspires to a worldliness unbound by either geography or race and suggests that multiple specificities exist', African Intimacies: Race, Homosexuality, and Globalization, Minneapolis: University of Minnesota Press, 2007, p 113.

10 Ashley Currier, Out in Africa: LGBT Organizing in Namibia and South Africa, Minneapolis: University of Minnesota Press, 2012, pp 10-15.

11 Ann Smith, 'Where Was I in the Eighties?', in Neville Hoad, Karen Martin, and Graeme Reid (eds), Sex and Politics in South Africa, Cape Town: Double Storey, 2005, pp 58-63.

12 Gerry Davidson and Ron Nerio, 'Exit: Gay Publishing in South Africa', in Edwin Cameron and Mark Gevisser (eds), Defiant Desire: Gay and Lesbian Lives in South Africa, New York: Routledge, 1994, pp 225-231.

13 See Brenna M Munro, 'Introduction: The Politics of Stigma and the Making of Democracy', in South Africa and the Dream of Love to Come: Queer Sexuality and the Struggle for Freedom, Minneapolis: University of Minnesota Press, 2012, p xiii; Chantal Zabus, 'Introduction: To Make Things Perfectly Queer', in Out in Africa: Same-Sex Desire in Sub-Saharan Literatures and Cultures, Suffolk: James Currey, 2013, pp 10-14.

14 Taiwo Adetunji Osinubi, 'Queer Prolepsis and the Sexual Commons: An Introduction', Research in African Literatures, 47(2), Summer 2016, p xv.

15 Ivan Vladislavic offers a fascinating account of the changing racial composition of Johannesburg where the narrator's growing discomfort in his favourite haunt Café Europa is explicitly linked to sexual and racial unease in The Restless Supermarket, Claremont: David Phillip, 2002. Vladislavic also meditates on the city in an aphoristic style reminiscent of Walter Benjamin in The Arcades Project in Portrait with Keys: The City of Johannesburg Unlocked, New York: Norton Press, 2006.

16 See Nigel Mandy, A City Divided: Johannesburg and Soweto, New York: St. Martin's Press, 1984; Alan Morris, Bleakness and Light: Inner-City Transition in Hillbrow, Johannesburg, Johannesburg: Witwatersrand University Press, 1999.

17 For an exploration of on such exchanges in Johannesburg, see Loren Landau, 'Transplants and Transients: Idioms of Belonging and Dislocation in Inner-City Johannesburg', African Studies Review, 49(2), 2006, pp 125-145; Abdoumaliq Simone, 'On the Worlding of African Cities', African Studies Review, 44(2), 2004, pp 15-41. Urban and cultural studies analysis of other African cities such as Kinshasa, Lagos, and Accra include Filip de Boeck, 'Kinshasa: Tales of the "Invisible City" and the Second World', in Okwui Enwezor et al. (eds), Under Siege: Four African Cities: Freetown, Johannesburg, Kinshasa, Lagos, Documenta 11, Platform 4, Ostfildern: Hatje Cantz, 2002, pp 243-286; Jonathan Haynes, 'Nollywood in Lagos, Lagos in Nollywood Films', Africa Today, 54(2), 2007, pp 131-150; Ato Quayson, 'Signs of the Times: Discourse Ecologies and Street Life on Oxford St., Accra', City and Society, 22(1), 2010, pp 72-96.

Accounts of the visibility and safety of gay men and lesbian women in urban South Africa often focus on the post-apartheid city with minimal reference to the situation in the 1980s and early 1990s. See Graeme Reid and Teresa Dirsuweit, 'Understanding Systemic Violence: Homophobic Attacks in Johannesburg and Its Surrounds', Urban Forum, 13(3), 2002, pp 99-126; Xavier Livermon, 'Queer(y)ing Freedom: Black Queer Visibilities in Postapartheid South Africa', GLQ: A Journal of Lesbian and Gay Studies, 18(2-3), 2012, pp 297323; Andrew Tucker, Queer Visibilities: Space, Identity, and Interaction in Cape Town, Oxford: Wiley-Blackwell, 2009. Gay newsletters and newspapers, such as Link/Skakel and Exit, are therefore valuable sources for analysing the situation during apartheid.

18 Loren Kruger, Imagining the Edgy City: Writing, Performing, and Building Johannesburg, Oxford: Oxford University Press, 2013, p 3. 
19 In chronological order, these are: Mandy, A City Divided; Lindsay Bremner, 'Reinventing the Johannesburg Inner City', Cities, 17(3), 2000, pp 185-193; Jo Beall, Owen Crankshaw, and Susan Parnell, Uniting a Divided City: Governance and Social Exclusion in Johannesburg, London: Earthscan, 2002; Keith Beavon, Johannesburg: The Making and Shaping of a City, Pretoria: University of South Africa Press, 2005; and Vladislavic's Portrait with Keys.

20 According to Ong, this trajectory has shifted in the late twentieth and early twenty-first century, such that the modelling and inter-referencing is now between cities in the global South.

21 The system of rigid racial classification was introduced by the Populations Registration Act of 1950. The South African population was divided into three racial groups: 'White', 'Black' ('African', 'Native', and/or 'Bantu') and 'Coloured'; further subcategorized into 'Cape Malay', 'Griqua', 'Indian', 'Chinese', and 'Cape Coloured'. These classifications were repealed by the Parliament in 1991.

22 Hoad, African Intimacies, p 72.

23 Mandy, A City Divided, p 89.

24 Kruger, Imagining the Edgy City, p 22.

25 Mandy, A City Divided, p 160.

26 Beall, Crankshaw, and Parnell, Uniting a Divided City, p 112.

27 'Gays Link Up', Link/Skakel (Johannesburg), May 1982, pp 1-2.

28 Mark Gevisser, 'A Different Fight for Freedom: A History of South African Lesbian and Gay Organisation from the 1950s to the 1990s', in Edwin Cameron and Mark Gevisser (eds), Defiant Desire: Gay and Lesbian Lives in South Africa, New York: Routledge, 1994, pp 14-86.

29 'Dial Pink', Link/Skakel (Johannesburg), May 1982, p 2.

30 Graeme Reid, How to Be a Real Gay: Gay Identities in Small-town South Africa, Durban: University of KwaZulu-Natal Press, 2013.

31 See John D'Emilio, Sexual Politics, Sexual Communities: The Making of a Homosexual Minority in the United States, 1940-1970, 2nd Edition, Chicago: University of Chicago Press, 1998. Revisions of D'Emilio's ideas on capitalism, urban migration, and gay identity include Robert Bailey, Gay Politics, Urban Politics, New York: Columbia University Press, 1998; Marc Stein, City of Sisterly and Brotherly Loves: Lesbian and Gay Philadelphia, 1945-1972, Chicago: University of Chicago Press, 2004.

32 These include the following articles: Karen Lotter, 'Is There a Lesbian Identity', Link/Skakel (Johannesburg), November 1982, p 10; Ann Smith, 'New Look at Social Lesbianism', Link/Skakel (Johannesburg), November 1982, p 4; Ann Smith, 'Lesbian Role Playing', Link/Skakel (Johannesburg), December 1982, p 11; Ann Smith, 'GASA Group for Women Proposed', Link/Skakel (Johannesburg), February 1984, p 6.

33 Buddies Advertisement, Link/Skakel (Johannesburg), January 1983, p 3.

34 This tendency is especially pronounced in Euro-American analyses of African social movements, marked by what Ashley Currier and Thérèse Migraine-George call 'Afro-pessimism' which includes lamentations about political corruption, violent conflict, pervasive indigence, and worsening health outcomes experienced by Africans. For Currier and Migraine-George, "the "victimage" produced by discourses of "African homophobia" stems from a particular intersection of area and sexuality studies: cynicism about African sociopolitical conditions and confining portrayals of lived gender and sexual diversity', 'Queer Studies/African Studies: An (Im) possible Transaction?', GLQ, 22(2), 2016, pp 281, 282.

35 While I use the term 'community' in this section, any notion of the gay community invoked by $L / S$ and Exit must take into account the exclusions already mentioned: white lesbians; black and coloured gays and lesbians; transgendered people of all races; those living in townships surrounding Johannesburg; and those who could not access the club and café culture thriving in Hillbrow and its environs because of their limited purchasing power.

36 Urvashi Vaid, Virtual Equality: The Mainstreaming of Gay and Lesbian Liberation, New York: Anchor-Doubleday, 1995, p 60.

37 Michael, 'You and the Law', Link/Skakel (Johannesburg), October 1982, p 7; 'You and the Law 2', Link/Skakel (Johannesburg), November 1982, p 7; 'You and the Law 3', Link/Skakel (Johannesburg), December 1982, p 7; 'You and the Law 4', Link/Skakel (Johannesburg), January 1983, p 9; 'You and the Law 5', Link/Skakel (Johannesburg), February 1983, p 11.

38 Michael, 'You and the Law 8', Link/Skakel (Johannesburg), June 1983, p 11.

39 'Exit Link/Skakel Enter Exit', Link/Skakel (Johannesburg), July 1985, p 1.

40 'Law Affects All', Exit (Johannesburg), October 1985, p 5.

41 Gevisser, 'A Different Fight for Freedom', p 61, my emphasis. 
42 Daniel Conway offers an illuminating account of the controversy by using Exit as a key source for his conclusions in 'Queering Apartheid: The National Party's 1987 “Gay Rights” Election Campaign in Hillbrow', Journal of Southern African Studies, 35(4), 2009, pp 849-863.

43 'Election Was Gay Victory', Exit (Johannesburg), June/July 1987, p 1.

44 'Hillbrow Can Be Key for Rights', Exit (Johannesburg), May/June 1987, p 1.

45 Wits Gay Movement, 'WGM Stand Clear', Exit (Johannesburg), June/July 1987, p 2.

46 Christopher Lorentz, 'Discrimination Abhorrent', Exit (Johannesburg), July/August 1987, p 2.

47 LAGO Collective, 'Misplaced', Exit (Johannesburg), July/August 1987, p 2.

48 Ebony's ad shows a stylized black and white shaded male torso. Browsers advertised their picture framing business in August 1984 by depicting figures shaded black and white in a sexually suggestive pose, perhaps indicating that interracial relations were allowable within private, though not public contexts, for after all the picture would be framed and kept at home. Another version of the Browsers ad in September 1984 depicts the sexualized figure of a woman to indicate that women customers were welcome.

49 'Whites Only', Link/Skakel (Johannesburg), December 1983, p 10.

50 Jens Rydström, 'Solidarity-With Whom? The International Gay and Lesbian Rights Movement and Apartheid', in Neville Hoad, Karen Martin, and Graeme Reid (eds), Sex and Politics in South Africa, Cape Town: Double Storey, 2005, pp 34-49.

51 'International Body Welcomes SA Gays', Exit (Johannesburg), August 1984, p 1.

52 Nkoli and 21 others associated with the United Democratic Front, a broad coalition of anti-apartheid groups, were accused of attempting to overthrow the state by violent means. These men were attending the funeral of twenty people shot dead by the police during a protest march against rent increases when they were arrested. The trial brought to national and international attention GASA's unwillingness to take a stand on the struggle for gay rights as connected to racial equality in South Africa.

53 'Gasa on Nkoli', Exit (Johannesburg), March/April 1986, p 1.

54 Ann Smith, 'Simon Part of a Greater Problem', Exit (Johannesburg), March/April 1986, p 5.

55 Saturday Group Notice, Link/Skakel (Johannesburg), June/July 1984, p 3. Roy Shepherd, Nkoli's partner at the time, was a white gay man.

56 'Glow Celebrates Pride', Exit (Johannesburg), June/July 1988, p 9.

57 Karen Lotter, 'Back in Africa: Simon Nkoli Reports Back on ILGA Conference and His Trip Overseas', Exit (Johannesburg), November 1989, p 7.

58 Mandisa Mbali, South African AIDS Activism and Global Health Politics, Ser. Global Ethics, Houndmills: Palgrave Macmillan, 2013, pp 55-56.

59 Simon Nkoli, 'Simon Nkoli Writes an Open Letter to Nelson Mandela-Reprinted from New York's Village Voice', Exit (Johannesburg), July/August 1990, p 16.

60 GLOW published its own newsletter from 1990 onwards. Often it was a record of meetings, activities, and important organizational briefs, rather than a primary vehicle of gay liberation as was the stated aim of $L / S$.

61 Reid and Dirsuweit, 'Understanding Systemic Violence', pp 103-106.

62 Reid and Dirsuweit, 'Understanding Systemic Violence', p 124.

63 Livermon, 'Queer(y)ing Freedom'.

64 Brenna M Munro, South Africa and the Dream of Love to Come: Queer Sexuality and the Struggle for Freedom, Minneapolis: University of Minnesota Press, 2012, p xxvi.

65 To a certain extent this is true of many countries in the Global South: in Uganda, homosexuality is punishable by life imprisonment; in Nigeria, it is punishable by imprisonment; in Jamaica homosexual acts are illegal under the 'buggery' and 'indecency' laws; in India, the Supreme Court of India recently repealed legislation that decriminalized homosexuality to recriminalize it as 'unnatural sexual acts.' Even in the face of such losses, it is unproductive to see LGBTQ activism in the South as merely imitative of the North without taking into consideration local histories of resistance.

66 My thanks to the dedicated staff of GALA, Johannesburg, in particular Gabriel Hoosain and Anthony Manion, who sourced the archives, helped with suggestions, and filled in the gaps. GALA librarian Carol Preston helpfully sourced missing page numbers for the reference list. Henk Botha kindly agreed to meet and talk about the newspaper, and introduced me to Johannesburg and its environs. Rich Rice's digital expertise was invaluable in the collection of the material, its organization, storage, and use. Thanks also to the two readers for Postcolonial Studies whose comments led to extensive revision of the article.

67 This work was supported by Texas Tech's College of Arts and Sciences Humanities Research Grants in 2011 and 2012 and a Faculty Development Leave in 2014. 